\title{
Investigation of curriculum of associate level in tourism and hospitality programs: Turkey case study
}

\author{
Veli Erdinç Ören ${ }^{1 a}$, and Tuba Şahin ${ }^{1}$ \\ ${ }^{1}$ Uşak University, Banaz Vocational School, Uşak 64500, Turkey
}

\begin{abstract}
Tourism sector is labor- intensive sector in rapidly increasing competition environment and so was increased to need employees who educated, qualified, skilled labor. While vocational and technical train, one of the most important criterion is curriculums. In this context, aim of this research conducted is to intend to bring recommendations about curriculum of associate level in tourism and hospitality programs in line with the purposes scrutinize and to reveal similarities and differences, tourism education can be standardized and its qualified can be increased. Data was collected by using a content analysis form throughout the vocational schools. Research population consist of 147 vocational schools. Collected data was analyzed with SPSS which is statistical analysis software. Result of the research shows that some of the lessons in the curriculum that is both mandatory and elective, some of the following lessons although first lesson is not the curriculum, second lesson is the curriculum.
\end{abstract}

Keywords: Associate level in tourism and hospitality education, curriculum, content analysis

\section{Introduction}

The fact that tourism which is a labor-intensive sector needs educated, qualified and quality labor power and especially intermediate staff cannot be denied. Vocational schools which are the fundamental organizations of the education system play an important role on meeting the needs to intermediate staff. However, it is necessary to take a cautious attitude as raising labor power on the base of the needs of the sector in order to maximize the efficiency of given education. In this context, the aim of the study is to identify the similarities and differences by the thought about whether the education which is given in tourism and hotel programmes of vocational schools is standard or not and at which degree the programmes in one school overlaps with one another, by analyzing the course plans of

a Corresponding author: erdinc.oren@usak.edu.tr

(C) The Authors, published by EDP Sciences. This is an open access article distributed under the terms of the Creative Commons Attribution License 4.0 (http://creativecommons.org/licenses/by/4.0/). 
tourism and hotel programme which give education on the pre-undergraduate level today. Analyzing the course programmes in the vocational schools and taking advices in terms of improvements of these course programmes in order to standardize the tourism education and to increase its qualification and quality show the importance of the study.

\section{Method}

Due to the reasons that content analysis being made to examine the structure of course plans followed at tourism and hotel management programmes in Turkey, that framework of the study being determined exactly and that directly showing the situation inside the framework, the study is designed as a descriptive model.

\subsection{Population and sample}

Target group of the study consists of vocational schools which give tourism education in Turkey. Certain schedules of vocational schools are analyzed in the working about the project of improvement the human sources by vocational training, [6] which is conducted in order to standardize the vocational training in Turkey. As a result of the project, Tourism and hotel management associate degree programmes are determined as study medium by thought that tourism education which has wide scope may adversely affect the analyzability of the study by making confusion of obtained data. Any illustration method is not used because of the reachability to all schools and their course programmes in study medium. According to data of "Student Selection and Placement Center", [8] as total, websites of 147 vocational schools are controlled, schedules of 81 vocational schools are examined. The fact that 66 vocational schools do not publish their schedules is disclosed by controlling websites of those schools. By this reason, research is conducted according to courses of rest of the vocational schools.

\subsection{Data collection and analysis}

Although courses being suitable to educate in the programmes determined in the context of İKMEP [6] are established in advance, institutions giving the respective trainings could prepare their course plans in line with their own wishes considering their interests, their qualifications and needs of their region. In this context, syllabus analysis form which consists of courses arranged for Tourism and Hotel Management programme is formed. In this form, courses are categorized under 8 headings. "Common Courses" for courses that all departments can use commonly; "Service", "Front Office" and "Housekeeping" for departments of service, front office, housekeeping in the following order; "Management", "Tourism Management" and "Foreign Languages" for general business, tourism management and foreign languages in the following order, "Others" for the courses which are not appropriate for these categories are chosen. In the study, data are collected by source scanning method. Relevant courses are examined according to course credits, term which they belong and whether or not they are elective. Course programmes are collected by examining relevant websites between 19th-26th August 2014. In the analysis of collected data, Social Sciences Statistics Packet Programme (SPSS in Turkish) has been used. In the process of analyzing data, descriptive analysis has been used. By the aim of identifying the structure of the course programmes of vocational schools which give tourism and hotel management course on the pre-undergraduated level, their frequencies and distributions are examined. Correlation analysis has been applied without paying attention to whether variables are independent or dependent in order to identify the 
direction, magnitude and significance of the relationship among them. In the case that Parametric Pearson Correlation Test cannot be applied, because of the applicability of the Kendall or Spearman Test, data are evaluated by analysis methods which are mentioned.

\section{Findings}

General profile of universities within the research were investigated with frequency analysis. Accordingly, the most data were collected from universities in the Marmara region. And then by using content analysis form, 62 different courses under the 8 headings were examined.

Table 1 above demonstrates the results regarding the eight basic headings of curriculum of vocational schools which give tourism education. In the section of common courses, while Information and Communication Technology 1 and Communication courses seem to be preferred at the 1st semester, there was a decrease in availability of Quality Assurance and Standards (Production) and First Aid courses. In the section of Service, Food and Beverage Service 1 and 2 courses exist nearly at every vocational schools and were followed each other during the 1st and 2nd semester. In the section of Front Office, there was an increase in availability of courses that are Front Office Service, Front Desk In The Room Procedures and Hospitality Automation System 1. However, Hospitality Automation System 2 was not on curriculum. In the section of Management, while General Accounting and Human Resource Management were preferred on curriculum, there was not Cost Accounting, Marketing Principles, Sales Management, Filing and Archiving and Economy. In the section of Tourism Management, General Tourism, Menu Planning, Hotel Management, Tour Operator and Travel Agency, Tourism Geography 1, Tourism Economy and Tourism Marketing have been preferred while availability of Guest Communication and Tourism Legislation were low. Naturally, Foreign Language courses are very important for vocational schools which give tourism education.

Frequency analysis were descriptively demonstrated the structure of courses given in the tourism and hotel management departments. At a later stage, eight basic headings of curriculum of vocational schools which give tourism education were investigated interrelatedly by correlation analysis.

A Kendall'stau_b very strong, positive correlation coefficient was computed to assess the relationship between Business Management 1 and Business Management 2 in the section of common courses. There was a positive correlation between the two variables, $\mathrm{r}=$ $0.927, \mathrm{n}=27, \mathrm{p}=0.000$. In the section of service, a Kendall'stau_b very strong, positive correlation coefficient was computed to assess the relationship between Food and Beverage Service 1 and Food and Beverage Service 2 courses. There was a positive correlation between the two variables, $\mathrm{r}=0.935, \mathrm{n}=51, \mathrm{p}=0.000$. Additionally, a Kendall'stau_b negative correlation coefficient was computed to assess the relationship between Room Service and Banqueting Service Management courses. There was a negative correlation between the two variables, $\mathrm{r}=-0.612, \mathrm{n}=19, \mathrm{p}=0.007$. A Kendall'stau_b negative correlation coefficient was computed to assess the relationship between Front Desk In The Reporting Process and Hospitality Automation Systems 1 in the section of Front Desk. There was a negative correlation between the two variables, $\mathrm{r}=-0.401, \mathrm{n}=28, \mathrm{p}=0.027$. Additionally, a Kendall'stau_b negative correlation coefficient was computed to assess the relationship between Front Desk In The Room Procedures and Hospitality Automation SystemS 1 in the section of front desk. There was a negative correlation between the two variables, $\mathrm{r}=-0.307, \mathrm{n}=38, \mathrm{p}=0.040$. 
Table 1. Curriculum Structure of Vocational Schools Which Give Tourism Education in Turkey in Terms of İKMEP

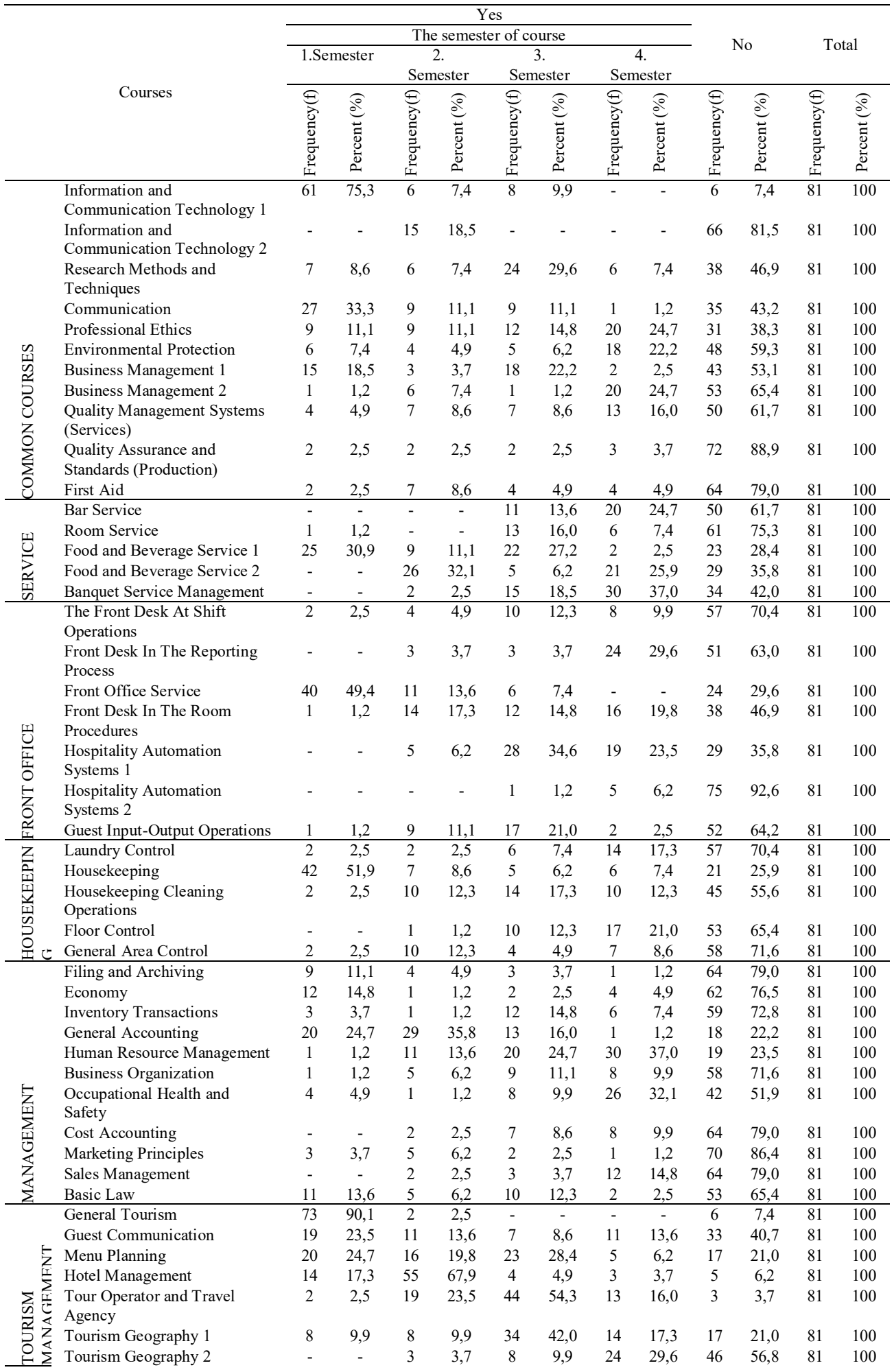




\begin{tabular}{|c|c|c|c|c|c|c|c|c|c|c|c|c|c|}
\hline & Tourism Economy & 27 & 33,3 & 36 & 44,4 & 6 & 7,4 & 6 & 7,4 & 6 & 7,4 & 81 & 100 \\
\hline & Tourism Legislation & 1 & 1,2 & 7 & 8,6 & 44 & 54,3 & 20 & 24,7 & 9 & 11,1 & 81 & 100 \\
\hline & Tourism Marketing & 4 & 4,9 & 10 & 12,3 & 42 & 51,9 & 19 & 23,5 & 6 & 7,4 & 81 & 100 \\
\hline & Foreign Language 1 & 79 & 97,5 & - & - & - & - & - & - & 2 & 2,5 & 81 & 100 \\
\hline & Foreign Language 2 & - & - & 72 & 88,9 & - & - & - & - & 9 & 11,1 & 81 & 100 \\
\hline & Foreign Language 3 & 1 & 1,2 & - & - & 4 & 4,9 & - & - & 76 & 93,8 & 81 & 100 \\
\hline tr & Foreign Language 4 & - & - & 1 & - & - & - & 4 & 4,9 & 76 & 93,8 & 81 & 100 \\
\hline$z \stackrel{巳}{\longleftarrow}$ & 2. Foreign Language 1 & 5 & 6,2 & - & - & 32 & 39,5 & 2 & 2,5 & 42 & 51,9 & 81 & 100 \\
\hline 0 & 2. Foreign Language 2 & - & - & 4 & 4,9 & 3 & 3,7 & 23 & 28,4 & 51 & 63,0 & 81 & 100 \\
\hline$\approx z$ & Professional English 1 & 2 & 2,5 & 12 & 14,8 & 56 & 69,1 & 1 & 1,2 & 10 & 12,3 & 81 & 100 \\
\hline 足匹 & Professional English 2 & - & - & 2 & 2,5 & 15 & 18,5 & 51 & 63,0 & 11 & 13,6 & 81 & 100 \\
\hline & Decorating Services & 2 & 2,5 & 5 & 6,2 & 5 & 6,2 & 30 & 37,0 & 39 & 48,1 & 81 & 100 \\
\hline & Turkish Language 1 & 73 & 90,1 & 3 & 3,7 & 1 & 1,2 & - & - & 4 & 4,9 & 81 & 100 \\
\hline 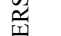 & Turkish Language 2 & 2 & 2,5 & 74 & 91,8 & - & - & 1 & 1,2 & 4 & 4,9 & 81 & 100 \\
\hline 荘 & History 1 & 71 & 87,7 & 5 & 6,2 & 3 & 3,7 & 1 & 1,2 & 1 & 1,2 & 81 & 100 \\
\hline 5 & History 2 & 2 & 2,5 & 71 & 87,7 & - & - & 3 & 3,7 & 5 & 6,2 & 81 & 100 \\
\hline
\end{tabular}

A Kendall'stau_b positive correlation coefficient was computed to assess the relationship between Filing and Archiving and Human Resource Management in the section of management. There was a positive correlation between the two variables, $r=$ $0.485, \mathrm{n}=16, \mathrm{p}=0.035$. In the section of management a Kendall'stau_b positive correlation coefficient was computed to assess the relationship between Economy and General Accounting, Marketing Principles, Basic Law. There was a positive correlation between the two variables, $(\mathrm{r}=0.659, \mathrm{n}=18, \mathrm{p}=0.002)$ Economy and General Accounting, $(r=0.791, n=7, p=0.040)$ Economy and Marketing Principles, $(r=0.713, n$ $=13, \mathrm{p}=0.007)$ Economy and Basic Law. A Kendall'stau_b positive correlation coefficient was computed to assess the relationship between Inventory Transactions and Business Organization. There was a positive correlation between the two variables, $\mathrm{r}=0.552, \mathrm{n}=12$, $\mathrm{p}=0.042$. A Kendall'stau_b positive correlation coefficient was computed to assess the relationship between General Accounting and Cost Accounting, Marketing Principles. There was a positive correlation between the two variables, $(\mathrm{r}=0.556, \mathrm{n}=16, \mathrm{p}=0.017)$ General Accounting and Cost Accounting, $(\mathrm{r}=0.625, \mathrm{n}=11, \mathrm{p}=0.026)$ General Accounting and Marketing Principles. A Kendall'stau_b negative correlation coefficient was computed to assess the relationship between Human Resource Management and Occupational Health and Safety. There was a negative correlation between the two variables, $\mathrm{r}=-0.310, \mathrm{n}=36, \mathrm{p}=0.042$. Finally, a Kendall'stau_b very strong, negative correlation coefficient was computed to assess the relationship between Marketing Principles and Sales Management. There was a negative correlation between the two variables, $\mathrm{r}=-0.905, \mathrm{n}=6, \mathrm{p}=0.034$. In the section of Tourism Management, $\mathrm{a}$ Kendall'stau_b negative correlation coefficient was computed to assess the relationship between Guest Communication and Hotel Management. There was a negative correlation between the two variables, $\mathrm{r}=-0.329, \mathrm{n}=47, \mathrm{p}=0.013$. A Kendall'stau_b positive correlation coefficient was computed to assess the relationship between Menu Planning and Tourism Economy. There was a positive correlation between the two variables, $\mathrm{r}=0.238, \mathrm{n}$ $=63, \mathrm{p}=0.032$. A Kendall'stau_b very strong, positive correlation coefficient was computed to assess the relationship between Tourism Geography 1 and Tourism Geography 2. There was a positive correlation between the two variables, $r=0.931, n=35, p=0.000$.

\section{Conclusion and discussion}

As a result, it is understood that courses having technological bases like Information and Communication Technologies, Automation Systems in Hotel Managements constitute majority in examined course plans. In this respect, when it is considered that today all hotel establishments are using automation systems, it could be said that trainings are given in 
parallel to sector needs. Along with that, it was determined that there are many basic business administration courses being thought at tourism and hotel management programs. It could be said that importance to basic business administration topics is given during preparing course plans in tourism and hotel management programs. Tourism management's service and front office specialized courses have been given a lot of importance too. Data obtained from the study shows that programs giving tourism and hotel management education at vocational schools in Turkey are aimed at training intermediate personnel who could work at service and front office departments mostly. In line with importance of foreign language in tourism sector, Foreign Language and Professional Foreign language courses mainly being in the programs supports that idea. When it is considered that especially service and front desk personnel gets in contact with hotel guests face to face, giving importance to Foreign Language courses in the programs is found appropriate.

Food and Beverages Service course is given during both semesters. However, it is understood that most of the programs giving Room Service course does not give Banqueting Service course. Although service implementation areas of both course are different, it could be thought that similar service application techniques are the reason of such choice in the programs. It is seen that the programs giving Front Office Reporting Operations course do not usually include Hotel Automation Systems course in their course plans. Also a similarly structured program having Room Operations at Front Office course does not include Hotel Automation Systems course. From this point of view it is determined that even their names are different, same courses in terms of content are included in the programs.

After examining strength of relations among Economy and General Accounting, Economy and Marketing Principles, and Economy and Basic Law courses, it is seen that the programs give importance to educate students in these topics. At the same time, it is understood from those relations that basic business administration courses are regarded as important. Also, not including structurally similar courses like Human Resources Management, Health and Safety, and Marketing Principles and Sales Management in most of the course plans at the same time is proving that the programs deliberately prepare their course plans.

Based on examination and observation made; it has been determined that there are some inconsistencies in course plans such as that some courses are planned as two semester successively but those courses are included as a selective in first semester and as a must in second semester; some courses are included as a must but then for following semesters included as a selective again; some courses are called as second even there is no course called as first for the same title; some courses are listed as selective but in fact students have no choice other than selecting those courses.

In this respect, it is thought that data obtained during the study performed shall help standardizing associate degree tourism education, increasing quality of tourism education by remedying the deficiencies and training qualified intermediate personnel being able to work just after graduation by establishing an ideal curriculum which is in concordance with the sector.

\section{References}

1. Akoğlan Kozak, M., (Akademik turizm eğitimi üzerine bir durum analizi. Muğla Üniversitesi Sosyal Bilimler Enstitüsü Dergisi, İLKE, Bahar 2009, Sayı 22, s. 1-20, 2009). 
2. Bayer, E., Türkiye meslek yüksekokulları turizm eğitimi kalitesinin geliştirilmesinde sanal yöntemlerin rolü. Süleyman Demirel Üniversitesi IIBF Dergisi, Sayı 3 (Güz), ss. 145-156, (1998).

3. Gürbüz, A. K. ve Dağdeviren, A., Lisans Düzeyinde Turizm Eğitimi Veren Kurumların Ders Programlarının Fonksiyonel Açıdan İncelenmesi. BalıkesirÜniversitesi SosyalBilimler Enstitüsü Dergisi, Cilt 10, Sayı 18, ss.157-167, (2007).

4. Heppner, P.P.; Kivlighan, D.M. ve Wampold, B.E., Research Design in Counseling (3th ed.). USA:CA, Thomson Learning, (2008).

5. Horn, L.V. ve Monsen, E.R., Research: SuccessfulApproaches, (3th ed.). (Editors: Monsen ve Horn) USA: American Dietetic Association, (2008).

6. İKMEP, 2010-2011 Akademik Yılında Uygulanacak olan MYO Öğretim Programları,[ Çevrim-içi:

http://ikmep.yok.gov.tr/?page=KatDown\&view $=$ list\&fileid $=152 \& \mathrm{c}=72 \& \mathrm{i}=88] \quad$ Erişim Tarihi: 21.08.2013, (2010).

7. Karataş, M. ve Babür S., Gelişen dünya'da turizm sektörünün yeri. KMÜ Sosyal ve Ekonomik Araştırmalar Dergisi, 15 (25), s. 15-24, (2013).

8. ÖSYM, Merkezi Yerleştirme İle Öğrenci Alan Yükseköğretim Ön Lisans Programları,[Çevrim-içi:

http://dokuman.osym.gov.tr/pdfdokuman/2013/OSYS/2013\%20\%C3\%96SYS\%20KO NT\%20KILAVUZU\%20BASKI\%20(Tablo\%203A\%20-\%20Tablo\%203B)_KB.pdf] Erişim Tarihi: 21.08.2013.

9. Sipahi, B., Yurtkoru, B.S. ve Çinko, M. (2010). Sosyal Bilimlerde SPSS'le Veri Analizi, (3.Baskı). İstanbul: Beta Basım.

10. Taylor, B., Kermode, S. ve Roberts, K., Research in Nursing and Health Care: Evidence for Practice, (3th ed.). USA:CA, Thomson Learning, (2004).

11. Turan, İ., Temel İstatistik. [Çevrim-içi: http://www.doguc.com/spssmenu.pdf], Erişim Tarihi: 02.06.2014, (2012).

12. Ural, A. ve K1lıç, İ., Bilimsel Araştırma Süreci ve SPSS İle Veri Analizi, (2. Bask1). Ankara: Detay Yayıncılık, (2006).

13. Ural, A. ve Pelit, E., Türkiye'de lisans düzeyinde turizm eğitimi veren yüksek öğretim örgütlerinin örgütleniş biçimleri. Abant İzzet Baysal Üniversitesi, Sosyal Bilimler Enstitüsü Dergisi. Say1 4, ss.218-228, (2002). 